Egyptian Journal of Aquatic Biology \& Fisheries

Zoology Department, Faculty of Science,

Ain Shams University, Cairo, Egypt.

ISSN $1110-6131$

Vol. 25(5): 337 - 354 (2021)

www.ejabf.journals.ekb.eg

\title{
Use of the microalga Scenedesmus obliquus (Turpin) Kutzing to remove some heavy
} metals from the industrial wastewaters

\author{
Yahia Mosleh $^{1 *}$, Jelan Mofeed ${ }^{1,2}$, El-Sayed Nafea ${ }^{1}$, Salma Heham ${ }^{1}$ \\ ${ }^{1}$ Aquatic Environmental Department, Faculty of Fish Recourses, Suez University, Egypt. \\ ${ }^{2}$ Faculty of Science, King Salman International University, Sinai, Egypt.
}

*Correspondence author: Yahia.mosleh@frc.suezuniv.edu.eg

\begin{abstract}
ARTICLE INFO
Article History:

Received: Sept. 27, 2021

Accepted: Oct. 3, 2021

Online: Oct. 16, 2021

Keywords:

S. obliquus, heavy metals, biosorption, biomass,

SEM.

Aquatic ecosystms may receive hazardous heavy metals resulting from the overconsumption of petrochemical products. Chemical and physical analysis of wastewater of certain petrochemical plant was studied; and pointed for the existence of $\mathrm{Cd}, \mathrm{Pb}, \mathrm{Zn}, \mathrm{Ni}, \mathrm{Cu}, \mathrm{Co}, \mathrm{Fe}$ and $\mathrm{Mn}$. The objective of this work is to study the effectiveness of immobilized Scenedesmus obliquus to remove such pollutants. Both fresh and dry biomass of the micro-green alga S. obliquus in immobilized form was used as low cost, efficient, and eco-friendly biosorbent for some heavy metals' removal. According to the results, the biosorption removal efficiency in general with all heavy metals was around $50 \%$ after 15 min. of treatment, and it reached $95 \%$ after $60 \mathrm{~min}$, while the efficiency rate remained stable or was slightly lowered after $120 \mathrm{~min}$. Moreover, the cited results clarify that $\mathrm{S}$. obliquus as biosorbent was more powerful in removing $\mathrm{Pb}, \mathrm{Cd}$ and $\mathrm{Fe}$ followed by $\mathrm{Ni}, \mathrm{Cu}, \mathrm{Mn}, \mathrm{Co}$, and $\mathrm{Zn}$ from the aqueous solution of petrochemical wastewater. For further verification, at the end of the treatment process, the algae cells were examined under the scanning electron microscope (SEM), which showed large clusters of heavy metals appeared adsorbed on the surfaces of the cells, which reflects the high efficiency of S. obliquus in removing heavy metals from industrial wastewaters. These results motivate us to apply the use of live or dry algae mass as an effective and safe method for the disposal of heavy metals and industrial effluents.
\end{abstract}

\section{ABSTRACT}

\section{INTRODUCTION}

Since the beginning of creation, water has been the mainstay of life, hence clean water resources are essential to all living organisms for their growth, reproduction and even survival. Domestic, agricultural and industrial wastewater especially mining, manufacturing and power generation had a negative impact on water quality and consequently on biota and Human health (Mosleh et al., 2012). Heavy metals (HMs) are released into the water environment mainly through, agricultural (pesticides, fertilizers) and industrial activities (painting, petroleum refining, mining activities, smelting, car exhausts, battery manufacturing and pigments, (Lesmana et al., 2009; Mosleh and Mofeed, 2014; Ardila et al., 2017). Heavy metals are elements with atomic weights ranged from (63.5 - 200.6) and a basic gravity greater 
than 5.0. Industrial wastewater is the main source of heavy metals contamination (Shanab et al., 2012; Mofeed and Mosleh, 2013). In recent years, pollution by heavy metals has become a big concern. This anxiety about heavy metals is due to they are not biodegradable but it has the ability to accumulate in living tissues, resulting in long-term sustainability in their negative impact on human health (Deng et al., 2008; Metwali et al., 2014; Mosleh et al., 2014; Ibrahim, et al., 2016).

Moreover, HMs can endanger ecosystems and public health because of their high mobility, lack of degradation, and high capacity to accumulate within all living beings. Also, it can participate in biological reactions that ruin vital processes within cells, tissues and organs promoting disease even if present with its low concentration in the environment (Topcuoglu $\boldsymbol{e t}$ al., 2003; Mosleh et al., 2006; Mosleh, 2013). However, some of these metals are essential micronutrients for plant growth (e.g., zinc, copper, manganese, nickel, and cobalt), whereas others may have unknown biological functions and are poisonous such as $\mathrm{Cd}, \mathrm{Pb}$ and $\mathrm{Hg}$ (Gaur and Adholeya, 2005). Mercury, cadmium, copper, zinc, lead, and nickel, among other harmful heavy metals, are the most common contaminants in both marine and freshwater (Travieso et al., 1999; Yu et al., 1999; Mehta and Gaur 2005; Singh et al., 2007; Mosleh, et al., 2014).

The conventional treatment methods for extracting biologically polluted heavy metals or effluents of wastewater include ions exchange, reduction of contaminants, chemical precipitation, membranes filtration, treatment of nanotechnology, electrochemical removal and advanced oxidation (Chalivendra, 2014). Additionally, there are several biological processes that use dead or alive, free or immobilized cells of algae or plant tissues, as cells have carbohydrates and polypeptides in their walls with, aldehydes, hydroxyl, amines ketones, carboxyl groups and phosphates responsible for metal caption adsorption and chelation (Wang, 2009). Unfortunately, using of these conventional processes is limited due to significant disadvantages, such as low selectivity, incomplete removal, high energy consumption, high cost or high toxic waste generation. Therefore, the world is constantly in need to find safe, lowcost and more effective alternative methods for extracting heavy metals from contaminated water.

Bioasorption is using the dried organisms as adsorbents (Mofeed and Mosleh, 2013; Chalivendra, 2014; Mofeed, 2017). Considering the biosorption mechanism; there are many ways for metal uptake by microbial cells (Ahalya et al., 2003; He and Paul, 2014), which can be classified according to different criteria depending on the cell structure according to the location where metal is removed from by extracellular accumulation. Where biological materials may have physiochemical properties that help to remove some heavy metals from wastewater by covalent bonding or ionic (He and Chen 2014; Zeraatkar et al., 2016; Salama et al., 2019). Metal biosorption from aqueous solutions has the potential to be a useful wastewater treatment strategy. It focuses on biological material's ability to absorb heavy metals ions from wastewater through metabolically mediated or physicochemical uptake pathways (including living or dead microbial biomass and their components, seaweeds, and so on) (Fard 
et al., 2011; Chalivendra, 2014). Biosorption is considered as an alternative powerful technique for extracting heavy metals from wastewater due to its great advantages such as low cost and high efficiency (kumar et al., 2006; Handojo et al., 2016), in addition, it can compensate for the drawbacks of commercial resins, which reduce the efficiency of adsorption in wastewaters to the lower metal concentrations (Eccles, 1999), this motivates its production in large quantities and in economical ways (Abdel-Aal and Mofeed, 2020). Also, algae are ideally suited for evaluating water quality and have been shown to be effective bioindicators because they have rapid reproduction rates, very sensitive responses to chemical changes, eutrophication and pollution, and receive a wide variety of typically specific species (Larson and Passy, 2012; Mofeed, 2020). Therefore, this study was aimed to evaluate the feasibility of using both dry and fresh biomass of the microalga $S$. obliquus in removing some heavy metals from industrial wastewaters.

\section{MATERIALS AND METHODS}

\section{Biological material}

\section{Microalgal biomass and stock solution}

Scenedesmus obliquus (Turpin) Kutzing (SAG 276-3a; Gottingen, Germany cultures; formerly S. acutus; Schlosser, 1994) was maintained in batch cultures containing $100 \mathrm{~mL}$ of Bold basal medium (BBM) (Bischoff and Bold,1963), under continuous aeration, at $22 \pm 1{ }^{\circ} \mathrm{C}$, illumination of $\mu \mathrm{mol} . \mathrm{m}^{-2} \mathrm{~s}^{-1}$ and placed on an orbital shaker (150 rpm). Every week the subcultures were made by adding $20 \mathrm{~mL}$ of one-week-old suspension into $100 \mathrm{~mL}$ of fresh growth medium.

\section{Harvesting of microalgae}

Harvesting of the algal biomass culture was done by centrifugation at $4000 \mathrm{rpm}$ for 10 min. The recovered biomass was washed in deionized water before being centrifuged again. Samples were dried in oven at $60{ }^{\circ} \mathrm{C}$ until the humidity reached the lowest level, and finally stored at $4^{\circ} \mathrm{C}$ for further use.

\section{Immobilization of $S$. obliquus in alginate beads and its application in heavy metal removal.}

Immobilization of microalgae have been used to facilitate evaluation of its biosorption capacity to heavy metals from aqueous solution, by using separating funnel packed with immobilized $S$. obliquus cells in sodium alginate beads. $4 \%$ sodium alginate solution was made by dissolving $4 \mathrm{~g}$ sodium alginate (Sigma-Aldrish) in $100 \mathrm{ml}$ distilled water and vigorously mixing for 30 minutes at $60{ }^{\circ} \mathrm{C}$ with continuous stirring for improved solubility. (Kumar et al., 2018). After cooling, $1 \mathrm{~g}(1 \% \mathrm{~W} / \mathrm{V})$ was added and stirred for 5 minutes at room temperature. The beads were made by dropping the cell suspension and sodium alginate combination into a cold sterile $2.5 \% \mathrm{CaCL}_{2}$ solution at room temperature in sterile conditions under gentle stirring. The beads were spherical with an average diameter of $1.5 \mathrm{~mm} 0.2 \mathrm{~mm}$ and a diameter of $1.5 \mathrm{~mm} 0.2 \mathrm{~mm}$. The resulting spherical beads were rinsed multiple times 
with autoclaved distilled water to remove unreacted $\mathrm{CaCL}_{2}$ from the surface, and then kept overnight at $4^{\circ} \mathrm{C}$ in autoclaved distilled water to stabilize and harden the beads by the same procedure, sodium alginate beads without incorporation of the $S$. obliquus biomass are also prepared and used as control. The beads were immersed in $0.2 \mathrm{M} \mathrm{HCl}$ buffer ( $\mathrm{pH} 7.2$ ) for storage and kept at $4{ }^{\circ} \mathrm{C}$ until needed. The experiment was carried out in a $100 \mathrm{~mL}$ separating funnel, containing alginate algal beads. The separating funnel's effluent wastewater was removed. The effluent was collected in $5 \mathrm{ml}$ at a flow rate of $3 \mathrm{ml} . \mathrm{min}^{-1}$ on a regular basis (every 30 minutes for up to 2 hours) and examined using inductively coupled plasma-atomic emission spectroscopy. The absorption of $S$. obliquus for metals ions was determined by the difference in the concentration of the heavy metals before and after absorption.

\section{Industrial wastewater sample.}

\section{Collection and preparation}

Water samples were collected from industrial drainage of Petrochemicals plant; the samples were kept in the dark and transported to the laboratory, where the chemicals investigations were done. Industrial wastewater samples were mixed well, and filtrated through millipore filtration system (Millipore Comp. 0.22) and stored at $4{ }^{\circ} \mathrm{C}$ to be used for chemicals analysis.

\section{Physico-chemical analysis}

The filtered industrial wastewater sample was taken in a polyethylene bottle in order to directly determine the physico-chemical parameters (Temperature, $\mathrm{pH}$, Nitrite $-\mathrm{N}$, Nitrate-N, Ammonia-N, and total dissolved salts, Chlorides, Sulfate, Reactive Silica, Hardness, Total Carbon, Alkalinity and Ortho-phosphate) as soon as reaching the laboratory, according to standard methods followed by American Public Health Association APHA, (1995). The concentrations of heavy metals in the samples were determined using atomic absorption spectrophotometry (kumar et al., 2008). Standard operating parameters were set and the hollow lamps for $\mathrm{Cd}, \mathrm{Zn}, \mathrm{Cu}, \mathrm{Mn}, \mathrm{Pb}, \mathrm{Fe}, \mathrm{Co}$ and $\mathrm{Ni}$ (Analytikjena Model Nova350) were used as radiation source and fuel was air acetylene. All the standard and samples were run in triplicate (Kunkel, 1973).

\section{Biosorption Experiment}

The scientific objective of this experiment was to evaluate the adsorption efficiency of S.obliquus as algae biosorpent depending on contact time and concentrations of the algal biosorpent. The biosorption experiments were carried out in batch mode, were, in different concentrations $\left(0.2,0.4,0.60 .8\right.$, and $\left.1 \mathrm{~g} . \mathrm{L}^{-1}\right)$ of the dried crushed algae biosorpent which were added to $100 \mathrm{ml}$ of the industrial wastewater in $250 \mathrm{ml}$ conical flask for designed intervals period of 15, 30, 60 and $120 \mathrm{~min}$ on an orbital shaker at $150 \mathrm{rpm}$. The temperature adjusted at $23 \pm 1{ }^{\circ} \mathrm{C}$ and $\mathrm{pH} 7.5$ before adding adsorbent. The suspended solids were separated out with GF/C filter. Heavy metal ion concentrations were then measured in the filtrate water. The residual concentrations of the tested heavy metals $(\mathrm{Cd}, \mathrm{Zn}, \mathrm{Cu}, \mathrm{Mn}, \mathrm{Pb}, \mathrm{Fe}, \mathrm{Co}$ and $\mathrm{Ni}$ ) in the filter were determined using atomic absorption spectrophotometry (Kunkel, 1973). The 
percentage removal and metal uptake efficiencies (Biosorption \%) of all adsorbents were determined with following expressions (Hashim and Chu, 2004).

$$
\text { Biosorption }(\%)=\left(\mathrm{C}_{\mathrm{i}}-\mathrm{C}_{\mathrm{f}}\right) / \mathrm{C}_{\mathrm{i}} \mathrm{X} 100
$$

The amount of metal adsorbed, Q ( $\mathrm{mg}$ metal/gram absorbent) was computed using the following equation (Chen, 2005):

$$
\mathrm{Q}=\left(\mathrm{C}_{\mathrm{i}}-\mathrm{C}_{\mathrm{f}}\right) \mathrm{V} / \mathrm{m}
$$

Where, $\mathrm{Q}=$ Amount of metal adsorbed $\left(\mathrm{mg} \cdot \mathrm{g}^{-1}\right) \mathrm{C}_{\mathrm{i}}=$ Initial metal concentration in solution $\left(m g . L^{-1}\right) C_{f}=$ Final metal concentration in supernatant after adsorption $\left(m g . L^{-1}\right) V=$ Volume of solution $(\mathrm{ml}) \mathrm{m}=$ Mass of the adsorbent $(\mathrm{g})$.

\section{Scanning electron microscope examination:}

At the end of the experiment the algal biosorpent, S. obliquus, in both the control and the treated with heavy metals were harvest and then fixed using $2.5 \%$ glutaraldehyde for $12 \mathrm{~h}$ at $4^{\circ} \mathrm{C}$. The fixed cells were dehydrated and washed by using a series of ethanol and then embedded in epoxy resin, following the method described by Sadiq et al., (2017), then observed using JEOL JSM 6510 model scanning electron microscope (SEM).

\section{Statistical analysis}

All the biosorption experiments were conducted in triplicates to substantiate the results. The data shown are the mean \pm standard deviations. Data were analyzed by Student's T test for independent samples. Analysis was performed using the SPSS 14.0 for Windows (SPSS, Michigan Avenue, Chicago, IL, USA), and the minimum significant level was set at 0.05. The multi-dimensional analysis; Cluster analysis was achieved by MVSP program using UPGMA cluster (Legendre and Legendre, 1998) to clarify the similarity in heavy metals removal efficiency.

\section{RESULTS}

Inspection of (Table 1) revealed that, total alkalinity values fluctuated between $6 \mathrm{mg} . \mathrm{L}^{-1}$ in industrial effluent wastewater before treatment and $4.4 \mathrm{mg} . \mathrm{L}^{-1}$ after treatment. While the total hardness value after treatment $\left(3.86 \mathrm{mg} . \mathrm{L}^{-1}\right)$ was higher than before treatment process, where it reached to $1.48 \mathrm{mg} . \mathrm{L}^{-1}$ (Table 1). The mean concentration of total dissolved solid (TDS) in industrial effluent is presented in (Table 1), where it was recorded as $180 \mathrm{mg} . \mathrm{L}^{-1}$ for industrial effluent wastewater before treatment and $112 \mathrm{mg} . \mathrm{L}^{-1}$ after treatment. Also, the $\mathrm{pH}$ of the samples varied from 6.2 to 7.8 , while the values of the free dissolved carbon dioxide during the whole period of investigation showed up $7.25 \mathrm{mg} . \mathrm{L}^{-1}$ in industrial effluent before discharge. However after industrial effluent wastewater discharged total carbon level reached to $6.5 \mathrm{mg} . \mathrm{L}^{-1}$. While chloride concentration fluctuated in narrow range between the untreated (16.76 mg. $\left.\mathrm{L}^{-1}\right)$ and the treated $\left(17.11 \mathrm{mg} . \mathrm{L}^{-1}\right)$ industrial effluent wastewater also other parameters such as; Phosphate, Sulphate, Nitrite, Nitrate, before treatment/and after treatment of industrial effluent wastewater as shown in Table (1). 


\section{Biochemical analysis.}

The data pertaining biochemical analysis revealed that, moisture content of S. obliquus was $10.2 \%$, as well as the ash content of $S$. obliquus was $57.13 \%$. While carbohydrates, protein and fat component of algal cells was $17.75,16.80$ and $0.36 \%$ respectively (Table 2)

Table 1: Physico-chemical parameters of the discharged petrochemical industrial effluent wastewater before and after treatment.

\begin{tabular}{|c|c|c|}
\hline \multirow{2}{*}{ Parameters } & \multicolumn{2}{|c|}{ Industrial wastewater $\left(\mathrm{mg.L}^{-1}\right)$} \\
\hline & Before treatment & After treatment \\
\hline $\mathrm{pH}$ (Unit) & $6.20 \pm 0.1$ & $7.80 \pm 0.89$ \\
\hline Temperature ${ }^{0} \mathrm{C}$ & $24.00 \pm 1.00$ & $24.4 \pm 1.20$ \\
\hline Sulphate mg. $\mathrm{L}^{-1}$ & $1.40 \pm 0.003$ & $0.20 \pm 0.16$ \\
\hline O. Phosphate mg. $\mathrm{L}^{-1}$ & $0.015 \pm 0.002$ & $0.022 \pm 0.04$ \\
\hline TDS (mg.L $\left.\mathrm{L}^{-1}\right)$ & $180.5 \pm 12.7$ & $112.30 \pm 4.8$ \\
\hline Ammonia (mg. $\left.\mathrm{L}^{-1}\right)$ & $5.50 \pm 0.027$ & $1.32 \pm 0.08$ \\
\hline Nitrate $\left(m g . L^{-1}\right)$ & $3.80 \pm 0.003$ & $2.20 \pm 0.01$ \\
\hline Nitrite (mg. $\left.\mathrm{L}^{-1}\right)$ & $0.20 \pm 0.003$ & $0.027 \pm 0.01$ \\
\hline Silica & $1.30 \pm 0.002$ & $0.027 \pm 0.0$ \\
\hline Chloride (mg.L $\mathrm{L}^{-1}$ ) & $16.76 \pm 0.81$ & $7.11 \pm 0.51$ \\
\hline Total alkalinity $\left(\mathrm{mg} \mathrm{CaCO} 3 \cdot \mathrm{L}^{-1}\right)$ & $6.00 \pm 0.12$ & $4.00 \pm 0.14$ \\
\hline Total carbon $\left(\mathrm{mg} \cdot \mathrm{L}^{-1}\right)$ & $7.25 \pm 0.32$ & $6.50 \pm 0.11$ \\
\hline Hardness $\left(\mathrm{mg} \mathrm{CaCO}_{3} \cdot \mathrm{L}^{-1}\right)$ & $1.48 \pm 0.07$ & $3.86 \pm 0.08$ \\
\hline
\end{tabular}

Table 2:- Biochemical analysis of $S$. obliquus biomass.

\begin{tabular}{|l|l|l|l|l|l|}
\hline \multirow{2}{*}{ Component \% } & moisture content & Fat & Protein & Carbohydrates & Ash \\
\cline { 2 - 6 } & $10.20 \pm 0.12$ & $0.36 \pm 0.01$ & $16.80 \pm 0.25$ & $17.75 \pm 0.35$ & $57.13 \pm 0.42$ \\
\hline
\end{tabular}

Data presented are mean $( \pm \mathrm{SD})$.

\section{Efficiency removal of heavy metals by the dried algal biomass}

The experiment was conducted to study the effect of dry S. obliquus on removal of some heavy metals $\left(\mathrm{Cd}, \mathrm{Pb}, \mathrm{Zn}, \mathrm{Ni}, \mathrm{Cr}, \mathrm{Cu}, \mathrm{Fe}\right.$ and $\mathrm{Mn}\left(\mathrm{mg} . \mathrm{L}^{-1}\right.$ ) from the petrochemicals industrial effluent wastewater. Results of heavy metals removal from the petrochemicals industrial effluent were depended up on, both biomass amount and contact time.

Dry S. obliquus adsorbed Mn according to concentrations and contact time presented in (Fig. 1). After $60 \mathrm{~min}$ of treatment the amount adsorbed of $\mathrm{Mn}$ at concentration 1 g.L. ${ }^{-1}$ reached to $74.2 \%$. While the best removal efficiency for Co by $S$. obliquus was at concentrations 1 g. $\mathrm{L}^{-1}$ of dry biomass after 60 and $120 \mathrm{~min}$ of treatment with adsorbed capacity reached to 63 and $68.22 \%$ respectively (Fig. 1). Data presented in (Fig. 1) showed that, with 1 g. $\mathrm{L}^{-1} \mathrm{~S}$. obliquus' biomass and at contact time 30 and $60 \mathrm{~min}$, the maximum removal percentage of $\mathrm{Cu}$ was 78 and $89.33 \%$ respectively. Also, data in (Fig. 1) showed that, the dry S. obliquus ability to removal $\mathrm{Pb}$ from the petrochemicals industrial effluent after 120 min of treatment with the concentration of $0.4 \mathrm{mg} . \mathrm{L}^{-1}$ was $81.4 \%$. While the $\mathrm{Pb}$ removal after 
120 min reached to $95.8 \%$ after the treatment of dry algal at concentration 1 g.L $\mathrm{L}^{-1}$ of dry algae. Also data in (Fig. 1) showed that the \%removal of $\mathrm{Zn}$ metal ion by S. obliquus after 15 min of dry biomass at concentration $0.2 \mathrm{~g} . \mathrm{L}^{-1}$ was $37 \%$. On the other hand the removal of $\mathrm{Cu}$ reached to $54.4 \%$ with the concentration 1 g. $\mathrm{L}^{-1}$ respectively after $60 \mathrm{~min}$. While data in (Fig. 1) presented the removal efficiency by $S$. obliquus for Ni metal ion from petrochemicals industrial effluent after 30 and 60 min with concentration 1 g.L. ${ }^{-1}$ of dry algal was 77.8 and $89 \%$ respectively. The removal percentage of $\mathrm{Cd}$ by dry $S$. obliquus presented at (Fig. 1) at concentration 0.2 g.L $\mathrm{L}^{-1}$ after $15 \mathrm{~min}$ the adsorbed capacity reached to $55.2 \%$, while after $60 \mathrm{~min}$ of treatment with concentration $1 \mathrm{~g} . \mathrm{L}^{-1}$ the adsorbed capacity reached to $95.15 \%$. While the data presented in (Fig. 1) showed that after 15 min \%removalof Fe reachedto $63.5 \%$ for Fe metal ion by dry $S$. obliquus at concentration 1 g.L. $\mathrm{L}^{-1}$. While after $60 \mathrm{~min}$ of treatment with the same concentration the removal percentage reached to $91 \%$.
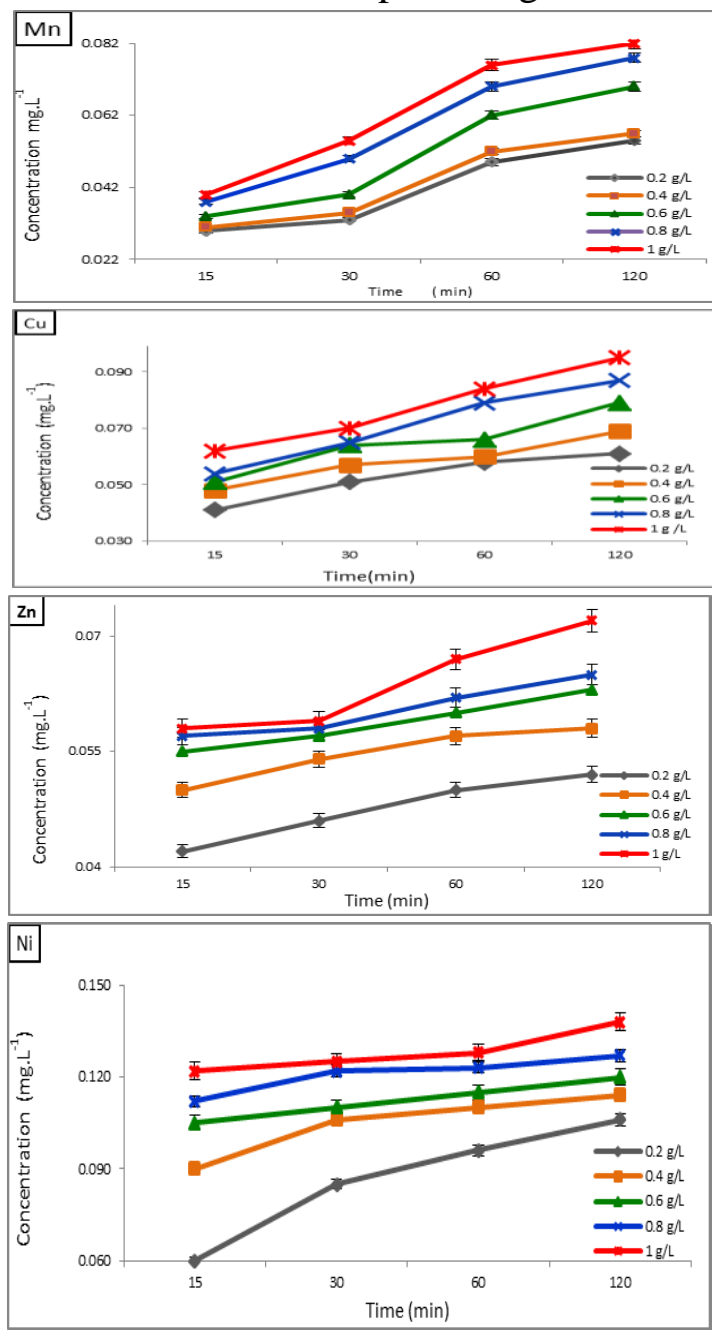
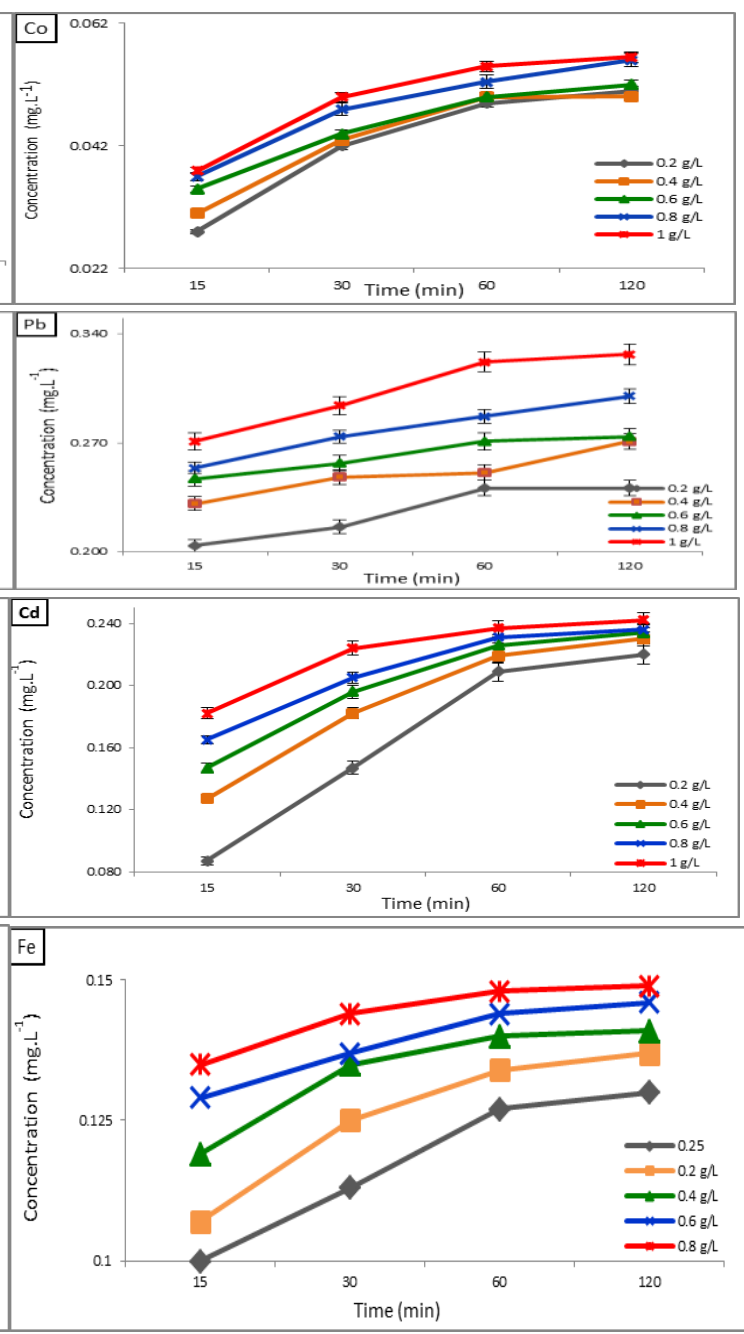

Fig. 1: The adsorbed amount of some heavy metals (mg. $\left.\mathrm{L}^{-1}\right)$ by dry S. obliquus after different time of treatment with dry algae. 


\section{Results of removing of metal ions by immobilized green microalgae $S$. obliquus.}

Data listed in (Fig. 2) according to biomass concentration the immobilized of S.obliquus showed the efficiency of $\mathrm{Ni}$ removal was $85.7 \%$ at concentration $0.4 \mathrm{~g} . \mathrm{L}^{-1}$ of algal solution beads after $120 \mathrm{~min}$ and it was $82.2 \%$ at concentration $0.8 \mathrm{~g} / \mathrm{L}$ after the same time.Also date presented (Fig. 2) indicated that the treatment of industrial wastewater containing immobilized S. obliquus beads theremoval \% of $\mathrm{Zn}$ was 48.3 and $52 \%$ after 60 min of treatment according to concentration 0.4 g.L. ${ }^{-1}$ and 1 g.L ${ }^{-1}$ of immobilized biomass respectively. Also (Fig. 2) presented the removal efficiency of S. obliquus beads for Mn metal ion at concentration 0.8 g. $\mathrm{L}^{-1}$ of fresh algal biomass was $59.7 \%$ after 120 min in like manner at concentration 1 g. $\mathrm{L}^{-1}$ of fresh algal biomass the percentage of removal reached to $68.2 \%$ within the same time. Data in (Fig. 2) showed alginate beads of S. obliquus was able to adsorb $\mathrm{Pb}$ after $60 \mathrm{~min}$ with efficiency reached to $88.6 \%$ at the concentration $0.4 \mathrm{~g} . \mathrm{L}^{-1}$ of fresh immobilized. While at concentration $0.8 \mathrm{~g} . \mathrm{L}^{-1}$ the efficiency was $92.71 \%$ after the same time. While date presented (Fig. 2) indicated that the treatment of industrial wastewater containing immobilized S. obliquus beads, the removal \% of Co was 48.3 and $65 \%$ after 60 min of treatment according to concentration 0.4 and 1 g.L $\mathrm{L}^{-1}$ of immobilized biomass respectively. While the bioremoval of $\mathrm{Cu}$ was shown in the removal percentage reached to $57.7 \%$ and $66.6 \%$ of fresh immobilized atconcentration $0.8 \mathrm{~g} . \mathrm{L}^{-1}$ after 60 and $120 \mathrm{~min}$ for S. obliquu respectively. Also data in (Fig. 2) showed that the initial concentration of $\mathrm{Cd}$ was $0.075 \mathrm{mg} . \mathrm{L}^{-1}$ the bioremoval efficiency by immobilized S.obliquus was $81.33 \%$ at concentration 0.2 g.L $\mathrm{L}^{-1}$ of algal solution after $60 \mathrm{~min}$, and ended up to $89.33 \%$ at concentration 0.8 g.L $\mathrm{L}^{-1}$ of fresh immobilized after the same time. While the data presented in (Fig. 2) showed that the treatment of industrial wastewater containing Fe with immobilized S. obliquus the biomass in sodium alginate-beadsremoved $84.8 \%$ of metal with concentration 1 g.L $\mathrm{L}^{-1}$ of algal biomass after 60 min. Nevertheless the removal percentage was $21.2 \%$ at concentration $0.2 \mathrm{~g} . \mathrm{L}^{-1}$ of algal biomass after 15 min by immobilized $S$. obliquus.

Regarding data in (Figs. 3-A, B and 4-A, B) reflect the similarity in biosorption efficiency of both fresh and dry S. obliquus biomass to the tested heavy metals from the aqueous solution of petrochemical plant, where it clarifies that it was more powerful in removing $\mathrm{Pb}$ and $\mathrm{Cd}$ followed by $\mathrm{Fe}$ which were grouped in one minor subgroup with a noticeable high similarity. On the other, in case of dry biomass; $\mathrm{Ni}$ and $\mathrm{Cu}$ were grouped in minor subgroup which related with less similarity with $\mathrm{Mn}$, Co and $\mathrm{Zn}$, however, all those heavy metals were grouped together but with high dissimilarity in case of immobilized fresh $S$. bliquus cells. 

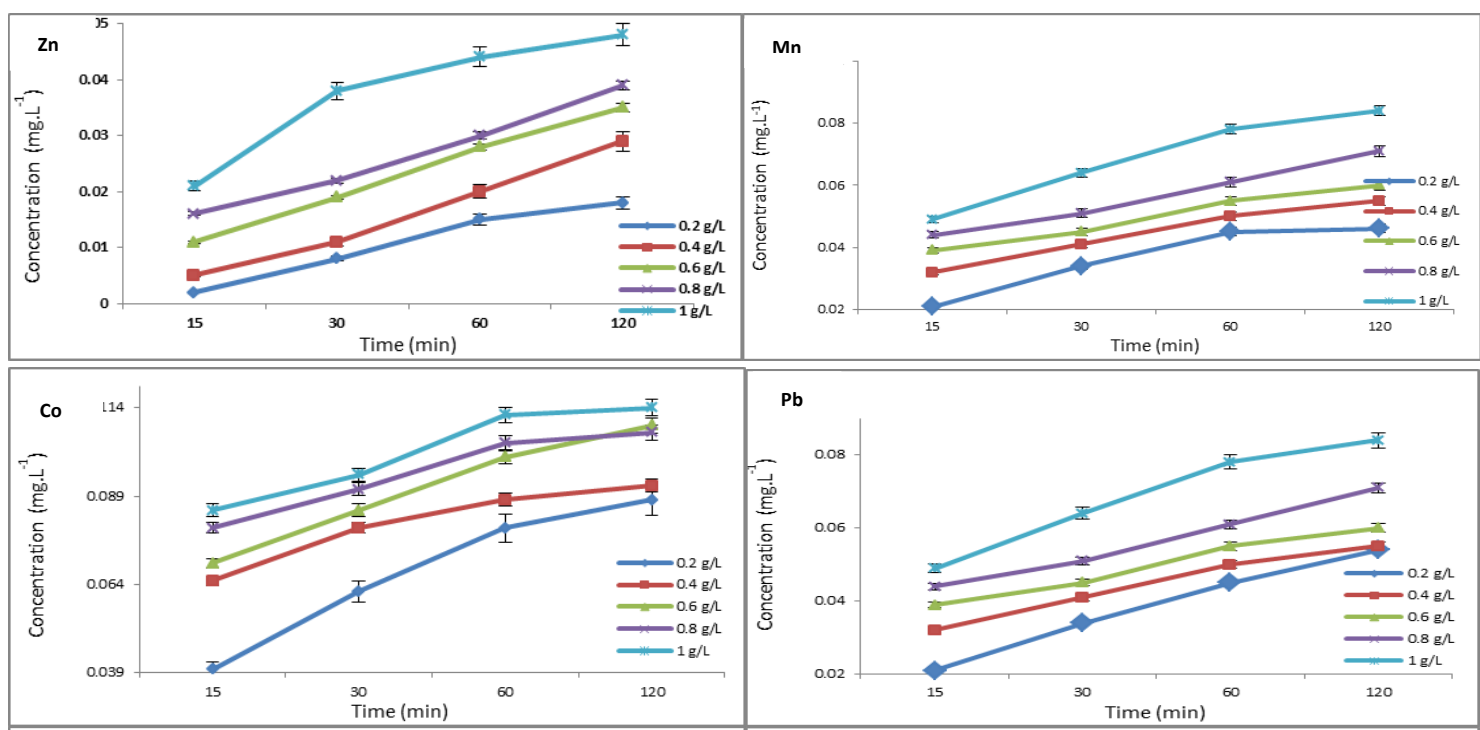

$\mathrm{Pb}$
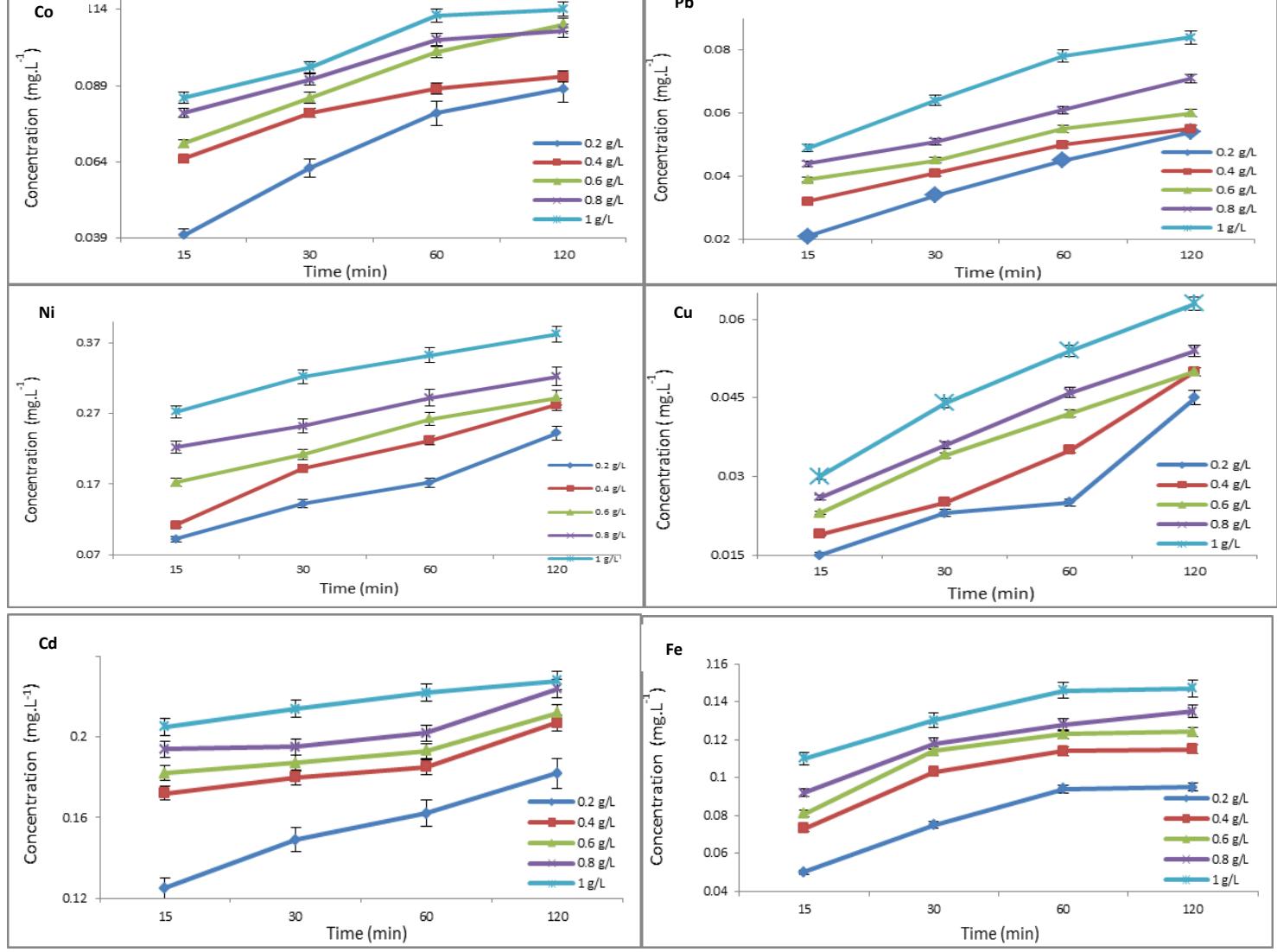

Fig. 2: Immobilization of S. obliquus biomass in alginate beads and its application in heavy metals removal from industrial wastewater.

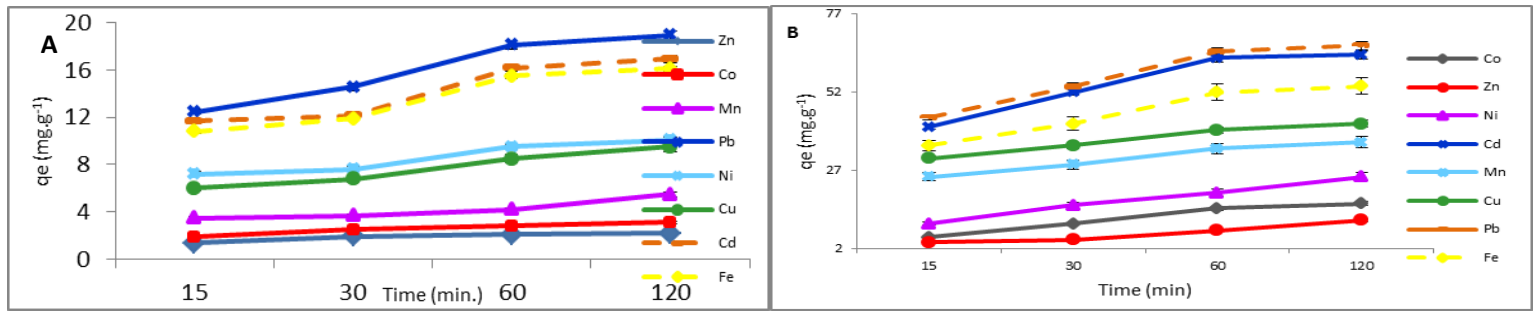

Fig. 3. Metal uptake capacity as a function of time using (A) dry algae S.obliquus and (B) immobilization of $S$. obliquus biomass in alginate beads. 

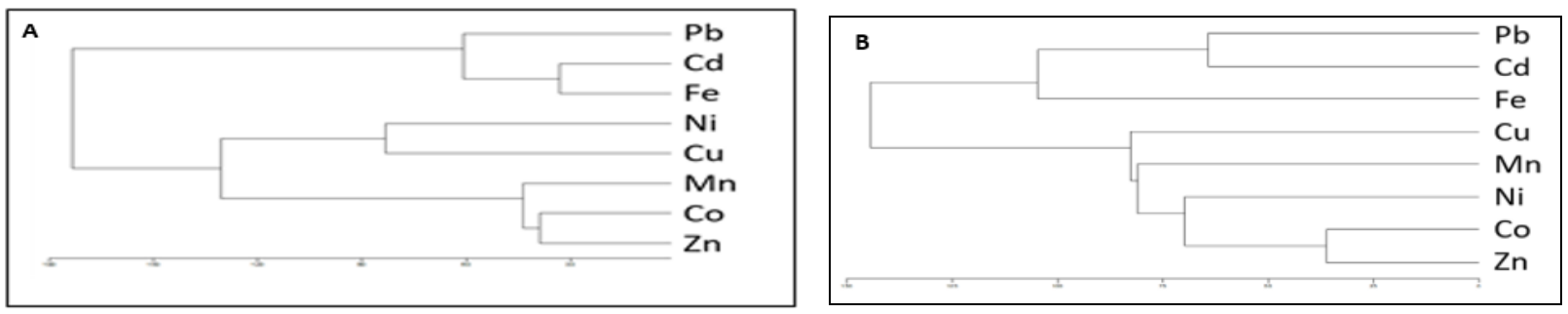

Fig. 4: Dendrogram produced by the Cluster analysis of the tested heavy metals adsorbed by (A) dry and (B) fresh biomass of $S$. obliquus; using UPGMA cluster.

\section{Scanning electron microscope examination of $S$. obliquus cells.}

$S$. obliquus cells were examined using scanning electron microscope (SEM) after exposure to the aqueous solution of petrochemical plant as well as the normal cell in the BBM medium. The resulted SEM images showed changes in the treated S. obliquus cells in compared to control cells (Fig. 5). The cells have lost the characteristic regular shape of $S$. obliquus cellsand aggregate in as irregular clustersaround heavy metal particles. Where, the fusion between cells is no longer limited to fusion with the lateral walls only, but some cells appeared to fuse with each other from the apical wall.The cells became smaller in width and more spindle in shape.
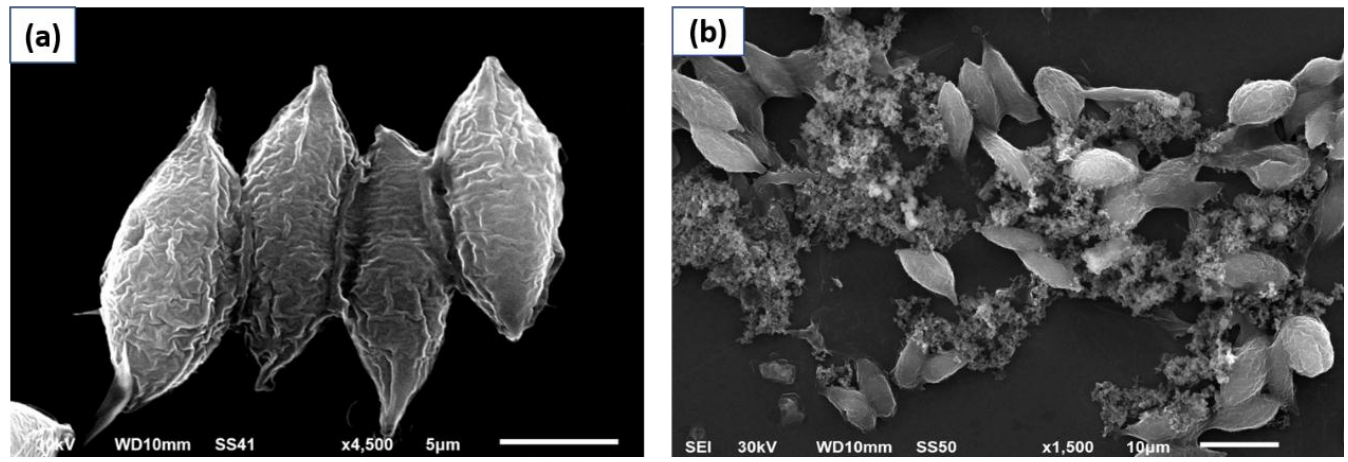

Fig. 5: Cellular structure of S.obliquus using scanning electron microscope (SEM), where (a) control and (b) after exposed to heavy metals aquas solution.

\section{DISCUSSION}

Increasing urbanization and industrialization have caused heavy metals to reach dangerously harmful levels in the environment, implying that heavy metals enrichment in many ecosystems is directly linked to human activity (Lasat, 2000; Estrella and Garcia, 2009; Harabawy and Mosleh, 2014). Mercury, cadmium, copper, zinc, lead, and nickel and other harmful heavy metals, are well-known freshwater and marine contaminants (Travieso et al., 1999; Yu et al., 1999; Mehta and Gaur 2005; Singh et al., 2007). In an ecological way, however, any metal or metalloid that pollutes the environment or cannot be decomposed 
biologically is considered a pollutant (and is therefore bio accumulated) it's possible to classify it as heavy metals (Estrella and Garcia, 2009).

During our investigation the value of TDS in industrial effluent water before treatment was $\left(180.5 \pm 12.69 \mathrm{mg} . \mathrm{L}^{-1}\right)$ higher than obtained value after treatment $\left(112.3 \pm 4.79 \mathrm{mg} . \mathrm{L}^{-1}\right)$, in which explained that the water had previously been treated. On the other hand, TDS isn't usually thought of as a major pollutant, it is not deemed to be associated with health effects. It's used to determine the aesthetic qualities of drinking water as well as an overall measure of the existence of a wide range of chemical pollutants (Ogemdi and Gold, 2018). While chloride levels have been shown to rise in direct proportion to pollution levels (Drakare et al., 2003; Gao and Song, 2005; Campbell et al., 2015). Petrochemical industrial effluent water of company had high chlorosity values ranged from $16.76 \mathrm{mg} . \mathrm{L}^{-1}$ in water before discharge while it was $17.11 \mathrm{mg} . \mathrm{L}^{-1}$ in water after discharge. It's appeared that chloride value became higher after the treatment than before. That result had the compliance to (WHO, 1990) which reported that water chloride may be increased by treatment processes in which chloride or chlorine is used. In similar studies (Aziz et al., 1996) investigated that Damietta estuary had a relatively high chlorosity values (9-20.5 g. $\mathrm{L}^{-1}$ ) higher sodium and chloride concentrations are known to cause plant toxicity. While carbon dioxide levels are predicted to nearly double in the next century (Muylaert et al., 2005; Mofeed, 2017) free and total carbon dioxide concentrations increased by increasing pollution (Schippers $\boldsymbol{e t}$ al., 2004). The result recorded for carbon dioxide within industrial effluent after water discharged into the sea was lower than in industrial effluent of factory before water discharge. It was reported by (Aziz et al., 1996) that agricultural and urban effluents both cause $\mathrm{CO}_{2}$ concentrations in water to rise, whereas industrial discharge affects total $\mathrm{CO}_{2}$ concentrations depending on the chemicals used. While the total alkalinity values in present study was $6 \mathrm{mg} . \mathrm{L}^{-1}$ in wastewater before treatment and reached to $4.4 \mathrm{mg} . \mathrm{L}^{-1}$ in wastewater after treatment so the result in our investigation observed high level of eutrophic conditions, according to study by (Campbell et al., 2015) who reportedthat the values of total alkalinity greater than $1.4 \mathrm{~m}$ equ.l indicate eutrophic conditions. The parameters that determine the amenability of waste water to biological treatment are alkalinity and pH (Jingxi Ma et al., 2020).

Nitrate, a nitric acid compound, is a photosynthetic autotroph and in some cases, a growth-limiting nutrient. Algae and other aquatic plants use it to make plant protein, which can then be used by animals to make animal protein. The nitrate levels in wastewater effluent were higher before treatment than after treatment. Nitrate is an important component of farm fertilizers because it is needed for plant uptake and development. Nitrate in the aquatic environment is the most heavily oxidized source of nitrogen (Atul and Narang, 2018; Kumar et al., 2018). Only inorganic forms of silica are used in the main cycle of silica, which includes the use of dissolved silicon and its degradation following the death of species (Raymont, 1980). Generally the dissolved reactive silica value in the present study area discharged from two points in the petrochemicals industrial effluent wastewater the first one was before treatment and it was higher than the second point which was after treatment. Agriculture 
activities such as mineral application, fertilizer application, extensive irrigation, and increased weathering were linked to an increase in silicate concentration (Juttner et al., 1996).

Algae are a wide category of eukaryotic organisms ranged from unicellular like Chlorella to multicellular like giant kelp and to huge brown algae that can grow up to 50 meters. Several reports had been showed that algae can absorb phosphorus, nitrate and some heavy metals leading to an enhancement quality of water (Davis et al., 2003; Li and Tao 2015). The benefits of algal biosorbent can compensate for the drawbacks of commercial resins, which have to reduce sorption efficiency at lower metal concentrations in wastewaters (Eccles, 1999). The majority of studies focus on the removal efficiency of metals by dry algal biomass, meaning that dead cells may absorb more metals than living cells (Mehta and Gaur, 2005). Bacteria or (bacterial exo polysaccharides), land plants or (their products), aquatic plants, algae, fungi, and peat moss have all gotten a lot of attention recently for their ability to remove heavy metals from the surrounding media (Sandau et al., 1996; Iyer et al., 2004). The discharge of unaffected tannery wastewater containing toxic substances of heavy metals in the ecosystem is one of the most important environmental and health challenges in our society (Mofeed et al., 2021). Therefore there is a rapidly need for the development of novel, ecofriendly, cost-effective and efficient, methods for the remediation of inorganic metals $(\mathrm{Hg}, \mathrm{Cd}$, $\mathrm{Cr}$ and $\mathrm{Pb}$ ) released into the environment. Biosorption is a physiochemical property of biological material that causes contaminants, primarily HMs, to be removed from industrial wastewater by covalent bonding (He and Chen 2014; Zeraatkar et al., 2016; Salama et al., 2019). Metal biosorption from aqueous solutions has the potential to be a useful wastewater treatment system. It focuses on biological materials ability to absorb heavy metals ions from wastewater through metabolically mediated or physicochemical uptake pathways (which can include dead or living algae, seaweeds and so on (Fard et al., 2011; Chalivendra, 2014). Protons compete with metal cations for binding sites because ion exchange is the mechanism of biosorption, and $\mathrm{pH}$ is the most important regulatory parameter that determines the availability of the site to the sorbate. The existence of the biosorbent and the availability of binding sites, as well as the biomass content, are two other significant variables in biosorption.

During the entire investigation period of present study the biosorption performance affected by two factors; contact time and biomass amount/weight the following was evident from data presented within the study. According to the contact time especially in first 15 min the biosorption efficiency was 50\%, however after about $60 \mathrm{~min}$ the efficiency reached to 95.8 and $92.7 \%$ or more for dry and fresh algae, after $120 \mathrm{~min}$, the efficiency rate remained stable or was slightly lower than $60 \mathrm{~min}$ at biomass weight 1 g. $\mathrm{L}^{-1}$, the biosorption capacity reached to the maximum while at biomass weight $0.2 \mathrm{~g} . \mathrm{L}^{-1}$ the capacity of biomass for binding metal ions was the lowest. Several reports had been showed that algae can absorb phosphorus, heavy metals and nitrateleading to an enhancement of the water quality (Davis et al., 2003). Metal biosorption experiments have been conducted with freshwater green algae (Chlamydomonas reinhardtii, Cladophora spp., Chlorella spp., and Scenedesmus spp.)where at low quantities of metals in aqueous solutions, algal biosorbents retain a high metal sorption effectiveness 
(Mehta and Gaur, 2005). Algal biosorbents have the potential to compensate for the deficiencies of commercial resins, which have reduced sorption effectiveness at lower metal concentrations in wastewaters. (Eccles, 1999). S. obliques immobilized in alginate beads may be used for cadmium bioremediation processes at low concentrations of the metals, since the presence of viable micro-algae biomass increases the alginate's removal capability (Liu $\boldsymbol{e t}$ al., 2020). Immobilizedcellsmoreeffective than free cells formetal removal by biomass due to increase inthecellwallpermeability (Dwivedi,1989). It is clear that, the biosorption capacity of immobilized beads of $\mathrm{S}$. obliquus for $\mathrm{Pb}, \mathrm{Cd}, \mathrm{Fe}$ and $\mathrm{Cu}$ metal ions was higher than immobilized beads for $\mathrm{Mn}$, Co and $\mathrm{Zn}$ during the entire period of our work.The treatment corresponding to alginate beads with immobilized $S$. obliquusbiomass is estimated to be the best for $\mathrm{Pb}$ elimination. At $60 \mathrm{~min}$, it was discovered that the micro-algae improves its metal removal potential at low metal concentrations, achieving a removal percentage of $59.67 \%$ with S. obliquus. The biosorption efficiency for $\mathrm{Pb}$ metal ion was in a small scale when compared to other metal ions of the present study within effluent waste water. The result by (Ardila $\boldsymbol{e t}$ al., 2017) investigated the immobilized $S$. obliquus had the ability to adsorb $\mathrm{Cr}$ metal ions from tannery wastewater, with removal levels up to $35.3 \%$ (Dwivedi, 1989). Another study by (Aksu, 1998) reported that immobilization appears to increase the amount of metal accumulated by biomass. it's worth mentioning that biosorbtion efficiency for $\mathrm{Pb}, \mathrm{Zn}$ and $\mathrm{Co}$ metal ions by two immobilized beads of green microalgae $S$. obliquus within petrochemical industrial effluent had the lowest capacity/or efficiency of biosorption in comparison to the overall biosorption potential of other metal ions ( $\mathrm{Fe}, \mathrm{Mn}, \mathrm{Cu}$ and $\mathrm{Cd}$ ) after the same time, during the whole period of investigation.Consequently as obvious from presented results and data the immobilized alginate beads of $S$. obliquus had the superiority in adsorbtion capacity for different metal ions.

\section{CONCLUSION}

Many studies have tried various methods for removal of heavy metal from industrial wastewater. Through the obtained results, testing the green micro-alga S. obliquus as a biosorbent proved its superior ability to remove heavy metals from aquas industrial wastewater that negatively adversely affect the environment. Where, during the first $15 \mathrm{~min}$ contact time the biosorption efficiency was about to 50\%, however after $60 \mathrm{~min}$. only the efficiency reached to $95.8 \%$. The results proved differences in the ability to remove different heavy metals by bio-accumulation in algal cells, where the highest results were for lead, cadmium and iron, followed by copper and nickel, then came the rest of the heavy metals (manganese, cobalt and zinc, in order). Which makes us take into account types of heavy metals to be removed from wastewater so that we can choose the appropriate adsorbent in order to obtain the best removal efficiency. So, we recommend usingS. obliquus as low-cost, eco-friendly and efficient biosorpent to eliminate some heavy metals from the petrochemical's industrial effluent wastewater. 


\section{REFERENCES}

Abdel-Aal, E. I.; Mofeed, J. (2020). Mass production of Arthrospira platensis on the livestock manure for use as a protein source in animal feed. Egyptian Journal of Aquatic Biology and Fisheries, 24 (7): 725-739.

Ahalya, N.; Ramachandra, T.V. and Kanamadi, R. D. (2003). Biosorption of heavy metals. Research Journal of Chemistry and Environment, 7 (4).

American public health association (APHA) (1985). Standard Method for the examination of water and wastewater, $17^{\text {th }}$ edn. American Public Health Association, Washington, D.C.

American public health association (APHA) (1989). Standard Method for the examination of water and wastewater, sewage and industrial wastes. $16^{\text {th }}$ Ed. New York, 1193.

Ardila, L.; Rubén, G. and Montenegro, L. (2017). Sorption capacity measurement of Chlorella Vulgaris and Scenedesmus Acutus to remove chromium from Tannery waste water. Conf. Ser.: Earth Environ. Sci., 83.

Atul, S. and Narang, H. K. (2018). Performance modeling and benchmarking of green supply chain management: an integrated fuzzy approach. Benchmarking, 25, 5.

Aziz, Q.; Inam, A. S. and Siddiqi, R. H. (1996). Long term effects of irrigation with chemical industry wastewater. J. Environment Sci. Health., A31(10): 2595-2620.

Bischoff, H. B. (1963). Some soil algae from enchanted rock and related algal species. Physcological Studies, 4: 1-95.

Campbell, K. M.; Gallegos, T. J. and Edward, R. L. (2015). Biogeochemical aspects of uranium mineralization, mining, milling, and remediation. Applied Geochemistry, 57: 206-235

Chen, S. (2005). Bioremediation potential of spirulina: toxicity and biosorption studies of lead. J Zhejiang Univ. SCI, Biology, 6B (3): 171-174.

Davis T. A.; Volesky, B.; Mucci, A. (2003). A review of the biochemistry of heavy metal biosorption by brown algae. water Research, 37:4311-4330.

Deng, L. P.; Zhu X. B.; Su, Y. Y.; Su, H. and Wang X. T. (2008). Biosorption and desorption of $\mathrm{Cd}^{2+}$ from wastewater by dehydrated shreds of Cladophora fascicularis. Chinese J Oceanol Limnol, 26(1): 45-49.

Drakare, S.; Blomqvist, P.; Bergstorm, A. and Jansson, M. (2003). Relatioships between picophyto plankton and environmental variables in lake along a gradient of water colour and nutrient cintent. Freshwater biology, 48: 729-740.

Dwivedi, S. (1989). Bioremediation of heavy metal by algae: current and future perspective. Journal of Advanced Laboratory Research in Biology, 195-199.

Eccles, H. (1999). Treatment of metal-contaminated wastes: Why select a biological process? Trends in Biotechnology, 17: 462-465.

Estrella, L. R. and Guevara-Garcia, A. A. (2009). Heavy metal adaptation. ELS Encyclopedia of Life Sciences. John Wiley and Sons, Ltd., Chichester, 1-9pp. 
Fard, F.; Azimi, A. and Bidhendi, G. (2011). Batch kinetics and isotherms for biosorption of cadmium onto biosolids. Desalination and Water Treatment, 28: 69-74.

Gao, X. and Song, J. (2005). Phytoplankton distribution and their relationship with environmental in Chanjiang estuary, China. Marine Pollution Bulletin, 50(3): 327-355.

Gaur, A. and Adholeya, A. (2005). Pro spects of arbuscul armycorrhizal fungi in phy to remediation of heavy metal contaminated soils. Current Science, 86(4): 528-534.

Handojo, D. U.; Keng, X. T.; Zhi, Y. D. C.; Jia, Y.; Jie, J. O. and Zheng B. (2016). Biosorption of heavy metal by algae biomass in surface water. Journal of Environmental Protection, 7: 1547-1560.

Harabawy, A. S. and Mosleh, Y. Y. (2014). The role of vitamins A, C, E and selenium as antioxidants against genotoxicity and cytotoxicity of cadmium, copper, lead and zinc on erythrocytes of nile tilapia, Oreochromis niloticus. Ecotoxicology and Environmental Safety, 104: 28-35

Hashim, M. A. and Chu K. H. (2004). Biosorption of cadmium by brown, green, and red seaweeds. Chemical Engineering Journal, 15: 249-255.

He, J. and Chen J.P. (2014). A comprehensive review on biosorption of heavy metals by algal biomass: materials, performances, chemistry, and modeling simulation tools. Bioresour Technol, 160: 67-78.

Ibrahim, M. I.; Asad, F. H. and Yahia A. A. (2016). Biosorption of toxic heavy metals from aqueous solution by Ulva lactuca activated carbon. Egyptian Journal of Basic and Applied Sciences, 3: 241-249.

Iyer, A.; Mody, K. and Jha, B. (2004). Accumulation of hexavalent chromium by an exopoly saccharide producing marine Entero bactercloaceae. Marine Pollution Bulletin, 49: 974997.

Jingxi, M. a.; Shuqing, W. V.; Ravi, S.; Supriya, B. and Anoop, K. S. (2020). Determination of physicochemical parameters and levels of heavy metals in food waste water with environmental effects. Bioinorganic Chemistry and Applications, 1-9.

Juttner, I.; Rothfritz, H. and Ormerdo, S. J. (1996). Diatoms as indicators of river quality in Nepalese Middle Hills with consideration of the effects of habitat-specific sampling. Freshwater Biology, 36: 475 - 486.

kumar, A.V.; AL Hashimi S.;and Hili. N. (2008). Investigation of kinetics and mechanism involved in the biosorption of heavy metals on activated sludge. Int. J. Green Energy, 5: 313-321.

kumar, R.; Vijayaraghavan, K.; Thilakavathi, M.; Iyer P. V. R. and Velan, M. (2006). Seaweeds for the remediation of wastewaters contaminated with zinc(II) ions. Journal of Hazardous Materials, 136: 791-799

Kumar, S. N.; Sahu, A. K. and Sahu, A. K. (2018). Green supply chain management assessment under chains of uncertain indices: an intellectual approach. Journal of Modeling in Management, 4: 973-993. 
Kunkel, R. and Stanley. E. M. (1973). Atomic absorption analysis of strong heavy metal chelating agents in water and waste water. Analytical Chemistry, 45: 1465-1468.

Larson, C. A. and Passy, S. I. (2012). Taxonomic and functional composition of the algal benthos exhibits similar successional trends in response to nutrient supply and current velocity. FEMS Microbiology Ecology, 80(2): 352-362.

Lasat, M. M. (2000). Phytoextraction of metals from contaminated soil: are view of plant/soil/metal interaction and assessment of pertinent agronomic issues. J. Hazard. Subst. Res., 2(5): 1-25

Legendre, P. and Legendre, L. (1998). Numerical ecology. Elsevier. Developments in environ-mental modeling. Elsevier Scientific Publ. Co., Amsterdam Netherlands 9: 419 pp.

Lesmana, S.; Febriana, N. F.; Soetaredjo, E. J.; Sunarso, y. and Ismadji, S. (2009). Studies on potential applications of biomass for the separation of heavy metals from water and wastewater. Biochemical Engineering Journal, 44: 119-41.

Li, P. S., and Tao, H. C. (2015). Cell surface engineering of microorganisms towards adsorption of heavy metals. Critical Reviews in Microbiology, 41: 140-149.

Liu, Q.;Yanqing, S.;Wenjing, W.; Changyu, L. and Guoqiang, Z. (2020). Remediation and its biological responses of $\mathrm{Cd}$ contaminated sediments using biochar and minerals with nanoscale zero-valent iron loading. Science of The Total Environment, 713: 1-10.

Mehta, S. K. and Gaur, J. P. (2005). Use of algae for removing heavy metal ions from wastewater: progress and prospects. Critical Reviews in Biotechnology, 25: 113-152.

Metwali, M.R., Gowayed, M.H., Omar, A. M. and Mosleh, Y. Y. (2013). Evaluation of toxic effect of copper and cadmium on growth, physiological traits and protein profile of wheat (Triticum aestivium L.), maize (Zea mays L.) and sorghum (Sorghum bicolor L.). World Applied Sciences Journal, 21 (3): 301-314.

Mofeed J. and Mosleh, Y. Y. (2013). Toxic responses and antioxidative enzymes activity of Scenedesmus obliquus exposed to fenhexamid and atrazine, alone and in mixture. Ecotoxicology and Environmental Safety, 95: 234-240.

Mofeed, J. (2017). Biosorption of heavy metals from aqueous industrial effluent by non-living biomass of two marine green algae Ulva lactuca and Dunaliellasalina as biosorpents, The Egyptian Society for Environmental Sciences, 16 (1): 43-52.

Mofeed, J. (2020). Impacts of $\mathrm{ZnO}$ nanoparticles on growth and antioxidant enzymes of the green alga Scenedesmus obliquus. Afr.J.Bio.Sc., 2(4): 1-12.

Mofeed, J.; Deyab, M.A; Mohamed, B. ; Moustafa, M.; Negm S.; El-bilawy E. (2021). Antimicrobial activities of three seaweeds extract against some human viral and bacterial pathogens. Journal of Biocell, 46(1): 247-261.

Mosleh, Y. Y. (2013). Role of dietary vitamins A, C, E and selenium in preventing heavy metals toxicity in nile tilapia (Oreochromis niloticus). Journal of Applied Plant Protection; Suez Canal University, 1: 15-23 
Mosleh, Y. Y. and Omar Almagrabi A. (2012). Heavy metal accumulation in some vegetables irrigated with treated wastewater. IJGHC, 2: 81-90.

Mosleh, Y., Mofeed, Y., Omar, A., Kadasa, M., El-Alzahrani, H. S. and Fuller, M. P. (2014). Residues of heavy metals, PCDDs, PCDFs, and DL-PCBs some medicinal plants collected randomly from the Jeddah, central market. Life Science Journal, 11: 1-8.

Mosleh, Y.Y.; Paris-Palacios, S. and Biagianti-Risbourg, S. (2006). Metallothioneins induction and antioxidative response in aquatic worms Tubifex tubifex (Oligochaeta, Tubificidae) exposed to copper. Chemosphere, 64: 121-128.

Mosleh, Y.Y. and Mofeed, J. (2014). Bio-chemical biomarkers in algae Scenedesmus obliquus exposed to heavy metals Cd, Cu and Zn. Life Science Journal, 11: 994-1004.

Muylaert, K.; Dasseville, R. and De, L. (2005). Dissolved organic carbon in the fresh water tidal reaches of the Schelde estuary. Estuarine, Coastal and Shelf Science, 64: 591-600.

Chalivendra, S. (2014). Bioremediation of wastewater using microalgae. Ph.D Thsis, School of Engineering of the University of Dayton $211 \mathrm{pp}$.

Ogemdi, I. K. and Gold, E. E. (2018). Physico-Chemical parameters of industrial effluents from a brewery industry in Imo State. Nigeria, Advanced Journal of Chemistry-Section A, 1(2): 66-78

Raymont, J. G. (1980). Plankton and productivity in the oceans. $2^{\text {ed }}$ (I). Phytoplankton, 476.

Sadiq, I. M.; Swayamprava D.; Chandrasekaran N. and Mukherje, A. (2017). Corrigendum to "ecotoxicity study of titania $\left(\mathrm{TiO}_{2}\right)$ NPs on two microalgae species: Scenedesmus sp. and Chlorella sp. Ecotoxicology and Environmental Safety, 142: 513521.

Salama, El- Sayed, Hyun, S. R.; · Subhabrata, D.; Moonis A. K.; • Reda, A. I.; Chang, S. W. and - Jeon, B. H. (2019). Algae as a green technology for heavy metals removal from various wastewater. World Journal of Microbiology and Biotechnology, 75: 3-19.

Sandau, E.; Sandau, P.; Pulz, O. and Zimmermann, M. (1996). Heavy metal sorption by marine algae and algal by-products. Acta Biotechnol., 16: 103-119.

Schippers, P.; Luring, M. and Scheffer, M. (2004). Increase of atmospheric $\mathrm{Co}_{2}$ promots phycoplankton productivity. Ecology Letters, 7: 446-451.

Shanab, S.; Essa, A. and Shalaby, E. ( 2012). Bioremoval capacity of three heavy metals by some microalgae species (Egyptian Isolates). Plant Signaling and Behavior, 7: 1-8.

Singh, A.; Mehta, S.K. and Gaur, J. P. (2007). Removal of heavy metals from aqueous solution by common freshwater filamentous algae. World J Microbiol Biotechnol, 23:1115-1120

Topcuoglu, S.; Guven, K. C.; Balkis, N. and Kibasoglu, C. (2003). Heavy metal monitoring of marine algae from the Turkish Coast of the balck sea,1998-2000. Chemosphere, 52: 1683-1688.

Travieso, L.; Benitez, F. and Dupeyrón R. (1999). Algae growth potential measurement in distillery wastes. Bull. Environ. Contam. Toxicol., 62: 483-489. 
Wang, J. L and Chen, C. (2009). Biosorbents for heavy metals removal and their future a review. Biotechnol. Adv., 27: 195-226.

World Health Organization (WHO), Guidelines for drinking-water quality, Health Criteria and other supporting information, Geneva, 1990.

Yu, Q.; Matheickal, J. T.; Yin, P. and Kaewsarn, P. (1999). Heavy metal uptake capacities of common marine macro algal biomass. Water Res., 33: 1534-1537.

Zeraatkar, A.K.; Ahmadzadeh, H.; Talebi, A. F.; Moheimani, N. R. and Henry, M. P. (2016). Potential use of algae for heavy metal bioremediation, a critical review. J Environ. Manage., 181: 817-831. 